
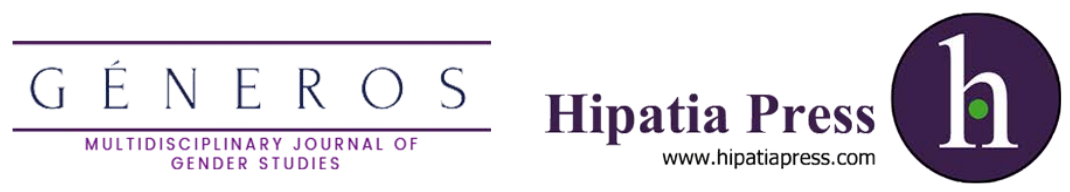

Instructions for authors, subscriptions and further details:

http://generos.hipatiapress.com

\title{
Negotiating Work Risks and Challenges of Street Vending Among Female Youths in Southwest Nigeria
}

Babatunde Joshua Omotosho ${ }^{1}$

Muhammed Yusuff Ola

1) Federal University Oye-Ekiti

Date of publication: February 25th, 2021

Edition period: February 2021 - June 2021

To cite this article: Omotosho, B.J. \& Ola, M. Y. (2021). Negotiating work risks and challenges of street vending among female youths in southwest Nigeria. Multidisciplinary Journal of Gender Studies, 10(1), 45-69. doi: 10.17583/generos.2021.4432

To link this article: http://dx.doi.org/10.17583/generos.2021.4432

\section{PLEASE SCROLL DOWN FOR ARTICLE}

The terms and conditions of use are related to the Open Journal System and to Creative Commons Attribution License (CC-BY). 


\section{Negotiating Work Risks and Challenges of Street Vending Among Female Youths in Southwest Nigeria}

Babatunde Joshua Omotosho

Federal University Oye-Ekiti

Muhammed Yusuff Ola

\section{Abstract}

This study investigated the experiences of young female traders in terms of risks and abuse in the course of the trade. For quantitative data, 120 copies of questionnaires were distributed to the respondents selected through two-stage-sampling techniques. For the qualitative, 6 in depth interviews and 4 key informants interviews were used to complement the quantitative data. Finding revealed that a majority $(76.7 \%)$ of the street traders were teenagers and came into the trade through their parent/guardians. Majority (90.0\%) of the respondents were aware of the risks involved; verbal and physical abuse also constituted a part of their experiences in the trade and this was often used to force them into sexual intercourse. As regards how they handled the risks and abuse, majority discussed with colleagues while some kept quiet regarding their experiences. However, in depth Interview (IDI) revealed that quite a number of them have adjusted to the experiences and may not be willing to share their experiences if not under pressure. Averting the risks associated with street trade might be challenging considering the attitude of the victims and their significant others regarding how they handle these risks and abuse.

Keywords: work, street trade, female youths, Africa, Nigeria 


\section{La Negociación de los Riesgos Laborales y los Retos de la Venta Ambulante entre Mujeres Jóvenes del Suroeste de Nigeria}

Babatunde Joshua Omotosho

Federal University Oye-Ekiti

Muhammed Yusuff Ola

\section{Resumen}

Este estudio investigó las experiencias de mujeres jóvenes comerciantes en cuanto a los riesgos y los abusos en el transcurso de la actividad comercial. Para obtener datos cuantitativos, se distribuyeron 120 copias de cuestionarios y se seleccionó a las personas encuestadas mediante técnicas de muestreo en dos fases. Para complementar los datos cuantitativos, se realizaron 6 entrevistas en profundidad y 4 entrevistas a informantes clave. Los resultados revelaron que la mayoría $(76,7 \%)$ de las mujeres jóvenes vendedoras ambulantes eran adolescentes y entraron en el comercio a través de sus padres o tutores. La mayoría $(90,0 \%)$ de personas encuestadas eran conscientes de los riesgos que entrañaba; los abusos verbales y físicos también formaban parte de sus experiencias en la actividad comercial y a menudo se utilizaban para obligarles a mantener relaciones sexuales. En cuanto a la forma de afrontar los riesgos y los abusos, la mayoría hablaba con sus colegas, mientras que algunas guardaban silencio sobre sus experiencias. Sin embargo, las entrevistas en profundidad revelaron que bastantes de ellas se han adaptado a las experiencias y pueden no estar dispuestas a compartir sus experiencias si no están bajo presión. Evitar los riesgos asociados al comercio ambulante puede ser un reto si se tiene en cuenta la actitud de las víctimas y de sus allegados con respecto a la forma en que manejan estos riesgos y abusos.

Palabras clave: trabajo, comercio ambulante, mujeres jóvenes, África, Nigeria 


\section{Omotosho \& Ola - Negotiating Work Risks and Challenges}

$\mathrm{V}$

ending is an age long practice in many African societies. It is an avenue for bringing the goods to the consumers with minimal stress while increasing the sales and profit margin of the vendor. This practice has survived the hurdles of modernity such that neighbourhood and major streets are besieged with vendors irrespective of age and gender. In contemporary societies, the unprecedented growth of cities with its attendant challenges in terms of unemployment, poor policy implementation and poverty have further increased the drive for street vending as one of the means of mitigating the harsh effect of these issues. The population of street vendors in the continent may be difficult to ascertain based on conflicting views on the subject (Bhowmik, 2005; Bromley, 2000). Notwithstanding, studies have pointed out that street hawking constitutes one of the main stay of the African continent and not less than 50 million people, as at 1999, were engaged in this type of trade (Jimu, 2005 \& Adeyinka, 2006).

Within the informal sector, street vending accounts for over $60 \%$ of all urban jobs and over $90 \%$ of all new urban jobs (Charmes, 2000). In modern times, the trade has spread from households to all spaces inhabited by humans. Thus, road sides, junctions, and highways and even offices and corporate organizations have been added to the coverage areas for vending. Street vending cuts across all age groups and each age group has its attendant (mis)conceptions and challenges. For female children and adolescents, which is the focus of this study, some of the fears regarding the trade relates to their wellbeing in terms of the perceptions regarding the street trade in the country.

Many of the concerns raised concerning the involvement of these female youngsters in the trade revolve around gender and age. Onakomaiya (1988), Gbadamosi (2006), and Adewumi (2009) have identified road mishaps as one of the major risks associated with the trade and the worst hit are women and children. Ikechebelu, Udigwe, Ezechukwu, Ndinechi, Joe-Ikechebelu, (2008), illustrated the reproductory challenges and sexual abuse as a result of the trade while Sherman (1992) \& Akpan and Oluwabamide (2010) also discussed the mental torture this activity causes for the young ones. In a study conducted by Ikechebelu et al. (2008), they discovered that 7 out of 10 street hawkers were sexually abused and infected with sexually transmitted diseases; Akpan and Oluwabamide (2010) in their study opined that these youngsters are exposed to stress, unwanted pregnancy and denied 

10(1)

opportunity for schooling. By implication, female street traders appears to be at a higher risk in the course of their businesses; the long and short term risks it portends for themselves and the country are enormous. Studies have also documented the continued increase of the trade in recent times; this is further exacerbated due to the rise in poverty levels in the country (Emerson 2009; Basu and Van, 1998) which force families and individuals to devise survival plans to mitigate the effects. In spite of the risks associated with the trade, it has continued to increase without restrictions in recent times. Drawing attention to the realities of these youngsters in terms of the risks they face and how they negotiate it thus becomes critical.

Investigating street trade and the involvement of female youths further becomes important for a number of reasons; while a number of studies have examined the issue of child labour (Omotosho and Adefolaju 2014), street trade, legal aspects and human rights perspectives, studies examining the issue of street trade among the young females is however limited. Studies have also pointed that when it comes to street trade, there is gender bias in favour of the male (Fetuga, 2005; Omotosho, 2009). Aside this, female youths appears to be the most affected regarding many of the risks associated with street vending in the literature. By implication, female street traders appears to be at a higher risk in themselves and for the future in the course of their businesses. Aside this, studies have also recognised the need for further investigations regarding the dynamics surrounding street trade as not much is understood regarding the subject (Kempe, 2007). Contributing to the extant literature through an exploration of the lived experiences of young female street traders therefore becomes essential. This study therefore sought to understand how young female traders negotiate risks in the course of their trades in Ado Ekiti south west Nigeria.

\section{Street Trade and gender in Africa: A Brief Review}

Literature is replete with studies regarding children and informal trade in Africa. Studies have documented that the trade is an important means of survival more especially as it relates to women (Fetuga, 2005). Large number of households and individuals within the continent may depend on this trade as a means of survival. Continentally, this sector is estimated to account for 


\section{Omotosho \& Ola - Negotiating Work Risks and Challenges}

sixty percent of all urban jobs and street trading accounts for the largest share of informal jobs (Charmes, 2000). In South Africa alone not less than threequarters of street traders are their household's main breadwinner and about one-third of street trader households have no other earners. By definition, "Street traders are those who belong to the informal economy and who trade in the streets." Witt (2000) further gave a clarification when he submitted that, "the term street trading, when referring to a specific activity within the 'informal' economy is accurate only in that it describes the physical presence of traders operating from a street.” International Labour Organisation (ILO, 2002) gave some defining characteristics of street trading especially as it relates to women and some of them are listed as follows: First, women dominate the field due to the customs and traditions which makes concentrate them in low income, low skilled and unorganised work spaces thus weakening their collective bargaining and organisational abilities. Second, street trading is an important source of survival for them; third, local governments are the key party with which street traders parley at the moment. Equally, street trading involves a broad collection of entrepreneurial bustles in the area of production, selling and buying.

A number of factors have been attributed to street trading in Africa. Some of the reasons were the influence of western economic policies like the Structural Adjustment Programmes (SAPs) of the 1980s and 1990s (Tsitsi and Agatha, 2000; Iyenda, 2001; Lonrenço-Lindell, 2004; Freund, 2007) coupled with the privatisation programme paved way to foreign goods and doing a fatal blow to the formal economy (Padayachee, 2010). Aside this, the influx of Chinese products to the continent has also been attributed to this proliferation of street trading within the continent as china products have littered almost all African cities

Defining sexual abuse among children, Convention on the Right of the Child act captures it to mean the act in which a child is used for sexual purposes UNICEF (2008, p10); it goes further:

The abuse is carried out by a person (adult or older child) whom the child trusts (parent, brother, a member of the extended family, teacher, guardian, etc.) or any other person in a position of power, authority or control over the child. The abuse may be physical, verbal or psycho-emotional. There is no informed consent from the child because of the pressure imposed by the adult, on whom the child is 


\section{GÉNEROS -Multidisciplinary Journal of Gender Studies, 10(1)}

dependent or feels dependent: this pressure can cloud the child's judgement and restrict the independence of his or her responses. The pressure may be physical, but is most often psychological: seduction, praise, reward, blackmail and threats, as often about keeping the act a secret as about the act itself. The concept of sexual abuse is complex because it covers not only physical acts (molestation, rape), but also behaviour (harassment, attempted molestation or rape, sexual remarks) or even intentions (emotional or material blackmail, using deception).

As argued by UNICEF (2008) above, it is a complex issue and children and youths in their bid to survive has been victims of sexual abuse. One of the issues surrounding the issue of sexual abuse in spite of the efforts of national governments across the continent to tackle it is mainly because not much is being done in the areas of monitoring and the implementation of the policies formulated (UNICEF, 2000). Some of the factors responsible for this include finance, lack of human resources to address this issue among the affected ones, coupled with lack of impunity for the offenders and among others (UNICEF, 2000).

This, however, may not suggest that nothing is being done to address this menace; scholars and policy makers considering the risks involved have taken a number of steps aimed at addressing this within the country over time but this has not yielded the expected results; for instance, a number of states in Nigeria promulgated decrees, laws, domestication of child rights act and in some cases arrested the affected people. These activities, however have not produced the desired expectation based on a number of issues ranging from poverty and lack of commitment on the part of the policy makers. One of the hawkers in Nigeria as reported by a newspaper had this to say while lamenting on the injustice of sending them away from the streets:

Unemployment is ravaging the nation. We cannot be going up and down stealing things. We believe in making a living through decent means and that is why some of us have resorted to hawking. Government should be able to see what they can do to reduce unemployment as it is the only means of alleviating our plight. I wrote my school certificate in 1995 but since then I have not been able to 


\section{Omotosho \& Ola - Negotiating Work Risks and Challenges}

gain employment. We are Nigerians; therefore, we should not be treated like common criminals (The Tide, 2010).

By implication, hawking has become a lifestyle that cannot be removed overnight. If that is the case, and going by what these youngster experience, one begins to wonder whether these young people know the implications of hawking on the street and if they do what are the ways they protect themselves from this risks. This study has therefore set for itself to understand the work risks among young female street traders and how they navigate them abuse in southwest Nigeria.

Theoretical explanation for this study is hinged on ecological theory which was developed by Urie Bronfenbrenner. The model argues that explaining abuse and neglect are multidimensional. To these theorists, no single factor can provide explanation on why some individuals or groups are at higher danger of social violence, while others are more protected from it (World Health Organisation, 2017). The theory argues that abuse or violence against an individual or group of persons is as a result of many factors occurring at four levels namely the individual, relationship, community and societal levels. At the individual levels, the model contends that personal history and natural factors determine to a large extent how individuals act, and the probability of becoming a victim or perpetrator of violence. Some of the factors that can bring about this include social and psychological factors namely child abuse, history of aggression, alcohol or substance abuse (WHO, 2017). The second level deals with relationship issues namely peers, family friends as playing active roles in being a victim or perpetrator of violence. The kind of friends kept by an individual can predispose to violence. The third level relates to the community contexts whereby the community plays a role in influencing someone to being a victim or committer of violence. Thus, the kind of social interaction within community spaces like school, neighbourhood, and workplaces can play active roles in violence. Some of the risk factors within these communities include violent neighbourhood, school and workplace aggression and among others. The last level discussed by the model is the societal level which deals with the social and economic factors within the society as it relates to aggression. Some of the variables like gender, culture, government policies, among others play active roles in inhibiting or promoting violence. The theory concluded that factors at different levels may interact in breeding violence. This theory becomes 

10(1)

crucial in this discourse considering its explanation of violence from social perspective. Child abuse is inherent within the society. The theory explains the dynamics of social relations in breeding violence. The society namely the family, peers and other variables like unemployment (breeding poverty) and aggression have created serious challenges for the vulnerable children trying to support themselves and their parents/wards in mitigating the effects of unemployment in the country. In the process of doing this, they become victims of various forms of abuse. While the theory did not say much about how the issue can be addressed, it however brings to the fore the fact that victims and the perpetrators are equally found within the society and solutions to the menace will equally be societal based. Using this theory, this study examines the interplay of 'ecology' as described by this model to explain child abuse in among young female street traders in Ado Ekiti, Nigeria.

\section{Methods}

The study was conducted in Ado Ekiti, Ekiti state, one of the states in southwestern Nigeria and predominantly inhabited by the Yorubas. The city is a one-town local government. Presently, the city can boast of three tertiary institutions and other institutions within its borders. Aside this, Ado Ekiti also houses many national and international organizations and also known for its peaceful atmosphere. A number of reasons prompted the researcher to carry out the study in this city; first, it is the state capital, and there is large concentration of educated and non-educated people from different parts of the country in the city. Also, the city witnesses tourists and individuals on business transactions coming to the city. Apart from that, the city is a gateway to the adjoining towns and villages as well as states, thus a large number of youths have made use of this opportunity to eke their livelihood through street trading. The study population consisted of 120 young female street traders within the age brackets of 7 and 16 based on the country's definition of who a child is. A two-stage sampling approach Involving Stratified random sampling and purposive sampling techniques were used to select the sample from the whole population in order to make room for total representation and accuracy. For the qualitative instrument, the study used 


\section{Omotosho \& Ola - Negotiating Work Risks and Challenges}

in-depth interviews and Key Informant Interviews to elicit information from a total of 6 female traders and 4 key informants comprising adult road side workers respectively. A combination of quantitative and qualitative data was used. Hence, quantitative data was analyzed using SPSS software. Frequency distribution tables were plotted to analyze all the questions. The hypothesis formulated for the study was also tested using chi square statistical method. As regards the in-depth interviews (IDI), they were analyzed through content analysis and quoted verbatim where necessary to support the quantitative data.

\section{Findings}

Table 1 describes some social and demographic features of the respondents. The majority of the respondents were teenagers constituting over $80 \%$ of the traders. About 24\% of the remaining respondents were between ages 7 and 12. From observation, the girls below 12 during the interview had their parents not far from them and also engaged in street trading. As regards their educational characteristics, 63\% were in school, especially in secondary school; some of them were also in elementary school. About $41 \%$ were however not in school. Some of the factors responsible for their being away from school could mean the need to start a trade. Also, some were engaged in the trade for personal reasons. For those who were out of school, they were interviewed on when they stopped schooling and majority of them claimed they stopped at primary school level. Findings on the occupation of their parents also revealed that $56.7 \%$ were traders; this of course may explain some of the reasons why a large percentage of youngsters were in street trading. Further, as regards their religious affiliations, majority (75.8\%) of them were Christians followed by Islam constituting $20.0 \%$. The religious affiliation of the majority of the respondents is due to the domination of Christianity in the area.

Table 1:

Percentage Distribution of Respondents by Age, Level of Education, Parents/Guardian Occupation and Religion

VARIABLES

\begin{tabular}{lll}
\hline Age & Frequency & Percentage \\
\hline $7-9$ years & 14 & 11.7
\end{tabular}



10(1)

\begin{tabular}{lll}
$10-12$ years & 14 & 11.7 \\
$13-14$ years & 39 & 32.5 \\
$15-16$ years & 53 & 44.2 \\
Total & 120 & 100.0 \\
\hline Educational status & Frequency & Percentage \\
\hline No formal education & 16 & 13.3 \\
In school & 63 & 52.5 \\
Out of school & 41 & 34.2 \\
Total & 120 & 100.0 \\
\hline If out of school, at what & Frequency & Percentage \\
level did you stopped? & & \\
\hline Primary & 36 & 87.8 \\
Secondary & 5 & 12.2 \\
Total & 40 & 100.0 \\
\hline Parent's/guardian's & Frequency & Percentage \\
occupation & & \\
\hline Traders & 68 & 56.7 \\
Self employed & 27 & 22.5 \\
Farmer & 13 & 10.8 \\
Civil servants & 12 & 10.0 \\
Total & 120 & 100.0 \\
\hline Religion & Frequency & Percentage \\
\hline Christianity & 91 & 75.8 \\
Islamic & 24 & 20.0 \\
Traditional & 5 & 4.2 \\
Total & 120 & 100.0 \\
\hline & &
\end{tabular}

Table 2 describes the factors accountable for respondents' involvement in street trade. The respondents were asked on what prompted them into street trading and about $61 \%$ of the respondents attributed the cause to the need to assist their parents. This of course corroborated the finding of table 1 on the occupation of the parents of these girls. Thus, it appeared they found themselves in the trade since their parents/guardian are already engaged in the trade. The rest of the respondents also used the money to meet the needs in the family. The respondents were further asked on what they do with the 


\section{Omotosho \& Ola - Negotiating Work Risks and Challenges}

proceeds from the trade; $76 \%$ said they gave the proceeds to guardians; $43.0 \%$ gave it to their parents and only one respondent $(0.8 \%)$ claimed she used it for personal reasons. During the IDI, the respondents that claimed they gave the money to their parents were asked on why they chose to do so and the IDI revealed that, they felt they needed to support their parents due to economic challenges, the response is quoted below:

It has not been easy for my parents to support everyone in the family. So I engage in street trading in order to support my parents. Part of the proceeds from this trade is used to augment my parents' income to meet our needs as a family. (IDI, Female, Ado Ekiti, Nigeria).

Another respondent who was also working for the parents also gave her submission on where the proceeds go to:

The wares I am selling belong to my parent and I deliver the proceeds to her as well". Many of the underage street traders interviewed were on the street hawking on the bidding of their parents/guardians. The financial benefits inherent in the trade constitute the major reason for it.

Table 2:

Percentage Distribution of Respondents by Factors Responsible for their Involvement in Street Trade

\begin{tabular}{llc}
\hline Why do you trade on the street? & Frequency & Percentage \\
\hline To help my parent/guardian & 73 & 60.8 \\
To help my family & 25 & 20.8 \\
To help my younger ones & 6 & 5.0 \\
Home feeding & 16 & 13.3 \\
Total & 120 & 100.0 \\
\hline Who keeps the proceeds from the & Frequency & Percentage \\
trade? & 1 & \\
\hline Self & 43 & 0.8 \\
Parent & 76 & 35.8 \\
Guardian & 120 & 63.3 \\
Total & & 100.0 \\
\hline
\end{tabular}



10(1)

The table below (Table 3) explicates respondents' perception of risks associated with street trade. The respondents were asked whether they are aware of the risks associated with street trade and the majority of the respondent claimed (90.0\%) they were aware of the associated risks; they were further interrogated to highlight some of the risks involved; $46.7 \%$ attributed it to road accidents; $28.3 \%$ felt the risk involved possible abduction while the rest of the sample (25.0\%) associated the risks to abuse. Investigating further the possible case of abuse, they were asked whether they are aware of the risks of pregnancy and sexually transmitted diseases through unprotected sex, $40 \%$ and $70 \%$ claimed they were aware respectively. Some of them claimed they got the information through television and classroom teaching. Some of their comments during the IDI: "Our teacher taught us in school that if we move close to boys, we would get pregnant. My mother also warned me not to play with boys" (IDI, Ado Ekiti). This was also corroborated by another respondent: "I normally watch the advertisement of HIV\& AIDS on television as well as programmes on HIV\&AIDS. Our teacher always tells us that we can contract diseases through unprotected sex" (IDI, Ado Ekiti).

It is interesting to note that these youngsters are informed regarding the risks associated with the trade. Within the country, a number of nongovernmental organisations have been focusing on the street traders to sensitize them on sex education. However, whether knowledge translates to safety may become another issue because in most cases these youngsters are on the street based on compulsion. Avoiding these risks may become difficult considering their age and the kind of trades they are engaged in which all make them further become vulnerable. It is interesting to note that they were only able to mention accident, abuse and unwanted pregnancy and infection as the major risks; they were oblivion to other risks ranging from the possibility of arrest by law enforcement agents; possibility of academic distraction; stress, as critical sources of risks they face. These, were however noted during the study.

Table 3:

Percentage Distribution of Respondents' Perception of Risks Associated with Street Trade

\begin{tabular}{lcc}
\hline $\begin{array}{l}\text { Are you aware of the risks involved in } \\
\text { street trade? }\end{array}$ & Frequency & Percentage \\
\hline Yes & 108 & 90.0
\end{tabular}


57 Omotosho \& Ola - Negotiating Work Risks and Challenges

\begin{tabular}{lll} 
No & 12 & 10.0 \\
Total & 120 & 100.0 \\
\hline If yes, what are the risks? & Frequency & Percentage \\
\hline Road accidents & 56 & 46.7 \\
Abduction & 34 & 28.3 \\
Abuse & 30 & 25.0 \\
Total & 120 & 100.0 \\
\hline $\begin{array}{l}\text { Are you aware of the risk of pregnancy } \\
\text { through unprotected sex? }\end{array}$ & Frequency & Percentage \\
\hline Yes & 48 & \\
No & 72 & 40.0 \\
Total & 120 & 60.0 \\
\hline Are you aware of the risk of contracting & Frequency & 200.0 \\
sexually transmitted infections (including & & Percentage \\
HIV/AIDS) through unprotected sex? & & \\
\hline Yes & 84 & 70.0 \\
No & 36 & 30.0 \\
Total & 120 & 100.0 \\
\hline
\end{tabular}

Further as regards their perception of risks involved in the trade the respondents that emphasised on abuse further emphasised on inappropriate touch (74.2\%); verbal abuse (75.8\%); penetrative sex $(11.7 \%)$ as shown in Table 4 below. Oral abuse does not necessarily mean insult; to the street children, it connotes inappropriate words that is suggestive of sex, and sometimes, it could mean insults hurled at them for not dancing to their seductive tunes. Some of their experiences regarding the kind of risks they face as regards abuse are captured below as recorded during the IDI sessions:

One day, when I was peddling my products along the street, a man called me that he wanted to buy orange, and as I was selling to him, he started touching my body and I quickly ran away (IDI, juvenile female, Ado Ekiti).

Apart from physical touch, other forms of abuse were verbal insult and a girl of 13 had this to say:

As I was selling my wares along the street one day, a motor cycle transporter called me, after buying plantain chips from me, he said to 

10(1)

me that my breasts are budding and that I am a pretty girl (IDI, juvenile female, Ado Ekiti).

A girl also narrated her ordeal while trading. Her responses are captured below:

As I was hawking along the street, a man called me that he wanted to buy something and he said I should come inside, and as I entered, he locked the door and rough-handled me. Please do not tell anybody (IDI, female, Ado Ekiti).

One of the street vendors also described her experience while trading. Some of her responses are captured below:

Some men always think we are sex objects. There was a time one boy in that shop said he wanted to be my boyfriend and I refused. He felt insulted that how could somebody of my status refuse his advances as that he was being nice and considerate to ask me out. Since then he has always been abusing me, calling me names and I am wondering whether friendship is by force (IDI, female, Ado Ekiti).

Many of these girls seems to be seen as sex objects by their male customers and failure to dance to their tunes may affect their sales and attract insults as well. From observation, many of the respondents have also developed street culture in terms of hurling insults at people. This of course is the expected norm as street traders are expected to be smart.

Table 4:

Percentage Distribution of Respondents' Experience Regarding Abuse while on the trade

\begin{tabular}{llc}
\hline $\begin{array}{l}\text { Have you experience inappropriate touch } \\
\text { while engaged in street trade? }\end{array}$ & Frequency & Percentage \\
\hline Yes & & \\
No & 89 & 74.2 \\
Total & 31 & 25.8 \\
\hline Do you experience verbal abuse? & 120 & 100.0 \\
\hline Yes & Frequency & Percentage \\
No & 91 & 75.8 \\
& 29 & 24.2
\end{tabular}




\begin{tabular}{llc} 
Total & 120 & 100.0 \\
\hline $\begin{array}{l}\text { Have you experienced abuse in form of } \\
\text { sexual intercourse? }\end{array}$ & Frequency & Percentage \\
\hline Yes & 14 & 11.7 \\
No & 106 & 88.3 \\
Total & 120 & 100.0 \\
\hline If yes, were you forced? & Frequency & Percentage \\
\hline Yes & 10 & 71.4 \\
No & 4 & 28.6 \\
Total & 14 & 100.0 \\
\hline
\end{tabular}

Table 5 investigates the basic description and characteristics of the abusers in terms of their age cohort, whether they are familiar with them and locations where these abuses took place. From the findings, 71.4\% of the respondents that claimed they have been abused before argued that they were mostly abused by adults; only $28.6 \%$ were their age mates. As regards whether they are familiar with the abusers, $57.1 \%$ claimed they were familiar with them while $42.7 \%$ claimed they were not familiar. Further, as regards the location of the abuse, $50.0 \%$ claimed it took place within residential places, while $35.7 \%$ claimed it took place within work environment.

Some of the vendors who experienced abuse had this to say during the interview: "I have known him before, he is my customer and that is why I entered the house... it was inside his house ...” (IDI, juvenile female, Ado Ekiti). Another female vendor interviewed shared her experience thus: "As I entered the house, he locked the door and rough -handled me” (IDI, juvenile female, Ado Ekiti).

Going by the Table and the submission of the vendors during the interview, it shows that victims of sexual abuse were familiar with the perpetrators who often used this as an opportunity to abuse them coupled with the fact that they believe they are vulnerable.

Table 5:

Percentage Distribution of Respondents' Description of their Abusers while on Street Trade

\begin{tabular}{lll}
\hline Status (Age) of abusers & Frequency & Percentage \\
\hline Adult & 10 & 71.4 \\
Age mate & 4 & 28.6 \\
Total & 14 & 100.0 \\
\hline
\end{tabular}



10(1)

\begin{tabular}{lll}
\hline Familiarity with abuser & Frequency & Percentage \\
\hline Known to the trader & 8 & 57.1 \\
Not known to trader & 6 & 42.9 \\
Total & 14 & 100.0 \\
\hline Location of the abuse & Frequency & Percentage \\
\hline Residential home & 7 & 50.0 \\
Office/business premises & 5 & 35.7 \\
In a Mechanic workshop & 1 & 7.1 \\
Inside a motor vehicle & 1 & 7.1 \\
& & \\
\hline Total & 14 & 100.0 \\
\hline
\end{tabular}

Table 6 describes the percentage distribution of the respondents regarding actions taken after they were being abused; the respondents were asked whether they confided in any one when the case of abuse took place, only $7.1 \%$ did not report the incidence to anyone. However, the rest reported to mother (28.6\%); sister (14.3\%); guardian (14.3\%); and girlfriends (35.7\%). The largest number of the respondents preferred to report the matter to their female friends. The respondents were asked whether any of the people they reported the matter to was able to take any action; responding, a majority (78.6\%) stated that they took action. They were further asked to mention some of the actions taken by the individuals they reported the matter to; responding, $64.4 \%$ claimed they were told not to go to such people again while $35.7 \%$ informed them to be careful. The respondents were further asked whether their guardians reported the case of abuse to the law enforcement agencies, 92.9\% said they did not. Crime reporting is an issue in Nigeria and elsewhere considering the stress involved and the stigma attached to abuse. Further abuse is even possible considering the history of the officers in developing countries.

Table 6:

Percentage Distribution of Respondents Regarding Action taken when physically abused

\begin{tabular}{llc}
\hline $\begin{array}{l}\text { Whom did you report to after being } \\
\text { sexually abused? }\end{array}$ & Frequency & Percentage \\
\hline Mother & 4 & 28.6 \\
Sister & 2 & 14.3
\end{tabular}


61 Omotosho \& Ola - Negotiating Work Risks and Challenges

\begin{tabular}{lll} 
Guardian & 2 & 14.3 \\
Friend (girl) & 5 & 35.7 \\
No one & 1 & 7.1 \\
Total & 14 & 100.0 \\
\hline Did any of them take any action? & Frequency & Percentage \\
\hline Yes & 11 & 78.6 \\
No & 3 & 21.4 \\
Total & 14 & 100.0 \\
\hline If yes What type of action? & Frequency & Percentage \\
\hline Warned me not to go there again & 9 & 64.4 \\
Told me to be careful & 5 & 35.7 \\
Total & 14 & 100.0 \\
\hline Did your guardian report the case to & Frequency & Percentage \\
the police? & & \\
\hline Yes & 1 & 7.1 \\
No & 13 & 92.9 \\
Total & 14 & 100.0 \\
\hline
\end{tabular}

In-depth interview further investigated the measures taken by the respondents in protecting themselves against the risks encountered. Many of them claimed they listened to their parents not to visit certain places that are prone to the danger; others claimed they don't hawk in lonely places or certain locations and people that they perceived to be dangerous; while some utilise religious means. From observation, the risk of sexual abuse that may likely occur to these youngsters may likely come from fellow traders and workers within same location. This is because they hardly leave the street environments while performing their trading activities.

Lastly, table 7 attempts to examine the statistical relationship between educational status and awareness about the risk of contracting infection (STIs) or getting pregnant. Findings revealed that a statistical relationship exists with these variables. Female street traders that have some levels of formal education are very much likely to understand the risks involved. This is evident in the IDI reports summarised earlier in this article. Quite a number of them that were knowledgeable about the risk involved became aware of the risk in school. Notwithstanding, knowledge may not in most instances translate to practise. However, from observation, some of these youngsters have been socialised into the culture within these environments. They appeared to know when a situation is risky and otherwise. Some of these 

10(1)

information are usually got from friends within these vicinities. Further, in depth interview reveals that no relationship between age and the risks of sexual abuse; many of them are vulnerable to the risks.

Table 7:

Chi-square $\left(x^{2}\right)$ Test of Association between Educational Status and Awareness of the Risk of Unprotected Sex.

\section{Educational Status}

\begin{tabular}{|c|c|c|c|c|c|c|c|}
\hline & $\begin{array}{l}\text { No } \\
\text { formal } \\
\text { education }\end{array}$ & $\begin{array}{l}\text { In } \\
\text { School }\end{array}$ & $\begin{array}{l}\text { Out of } \\
\text { School }\end{array}$ & Total & $\mathrm{df}$ & $\begin{array}{l}x^{2} \\
\text { cal }\end{array}$ & $\begin{array}{l}x^{2} \\
\text { tab }\end{array}$ \\
\hline $\begin{array}{ll}\text { Awareness } & \text { Yes } \\
\text { of risk of } & \\
\text { pregnancy } & \end{array}$ & $\begin{array}{l}5 \\
(31.3 \%)\end{array}$ & $\begin{array}{l}32 \\
(50.8 \%)\end{array}$ & $\begin{array}{l}11 \\
(26.8 \%)\end{array}$ & $\begin{array}{l}48 \\
(40.0 \%)\end{array}$ & 2 & 6.532 & 5.99 \\
\hline
\end{tabular}

11

\begin{tabular}{lllllllll} 
& No & $(68.8 \%)$ & 31 & 30 & 72 & & & \\
& & & $(49.2 \%)$ & $(73.2 \%)$ & $(60.0 \%)$ & & & \\
& Total & 16 & 63 & 41 & 120 & & & \\
& & $(100 \%)$ & $(100 \%)$ & $(100 \%)$ & $(100 \%)$ & & & \\
\hline $\begin{array}{l}\text { Awareness } \\
\text { of risk of } \\
\text { contracting }\end{array}$ & Yes & 14 & 38 & 32 & 84 & 2 & 6.411 & 5.99 \\
STIs & & $(87.5 \%)$ & $(60.3 \%)$ & $(78.0 \%)$ & $(70.0 \%)$ & & & \\
\hline
\end{tabular}

\begin{tabular}{lllll}
\hline \multirow{2}{*}{ No } & 2 & 25 & 9 & 36 \\
& $(12.5 \%)$ & $(39.7 \%)$ & $(22.0 \%)$ & $(30.0 \%)$ \\
\multirow{2}{*}{ Total } & 16 & 63 & 41 & 120 \\
& $(100 \%)$ & $(100 \%)$ & $(100 \%)$ & $(100 \%)$ \\
\hline
\end{tabular}

\section{Discussion}

The study investigated the negotiations of young female traders with the risks and abuse encountered in the course of their activities. One of the issues from this study relates to the fact that so many of the young people were not in 


\section{Omotosho \& Ola - Negotiating Work Risks and Challenges}

school even when they claimed to be enrolled in school. Street trade can be a whole day activity or a after school activity and a number of factors can determine this; the place of residence of the child in terms of whether she stays with biological parents or not, the poverty level of the guardian/parents and the nature of the jobs they do. International Labour Organisation (2013) and Mapaure (2009) demonstrated the linkage between school attendance and poverty. While this study affirms such connections, further evidence in the course of the study revealed that poverty alone cannot explain school attendance; rather factors such as whom the child stays with play a key role; in addition, education at the primary level in Nigeria is compulsory and relatively free in some parts of the country thus making poverty as the sole explanation for school attendance implausible. From the study, evidence revealed that a majority of the children that live with their biological parents stayed in school up to secondary school level (though they may not complete it). The attitude of their guardians therefore appears to play a greater role in school attendance of these children.

As regards the reasons for the involvement of young girls on the streets for trade, evidence from this study suggests that poverty played an important role in this; previous studies have equally affirmed the linkage between these variables (Basu, 1998; Bhat \& Rather, 2009; Akarro \& Mtweve, 2011). However, the findings from this study also brings to fore the role of culture and rural-urban migration as factors responsible for the presence of the girls on the streets. Quite a handful of these children were in the trade because their parents/guardian were involved in it thus limiting their choice. Further, the role of rural-urban migration which dates back to the colonial era whereby young people were always interested in moving to the city to stay with relations is still at force. Many of the children staying with their guardians in this study came from the rural areas; they were eager to move (or be sent) to the city not minding the cost. As a matter of fact, some of them didn't know the nature of what they were coming to do in the city in the first instance. City keeps attracting people because of the perceived benefits in terms of better facilities and prestige.

Further as regards the level of awareness of the respondents regarding the risks involved in the trade, it is interesting to note that majority of the respondents were conscious of this. However, avoiding these risks appear to go beyond the ability of these girls. Studies have documented that street 

10(1)

traders are in the trade out of compulsion (Skinner, 2008). Whether their awareness of the risks would be of help may however become difficult. A majority of the girls were not in the trade out of their own volition; first they were in the trade through parents/guardians; in terms of experience, they are still young thus making them vulnerable and, also, the roles of the parents/guardians in managing the incidence of abuse was nothing to write home about. Ability to avoid risks on the part of these children will be dependent on maturity coupled with strong and effective significant others and relevant institutions. Findings revealed that apart from physical abuse, oral abuse namely insults constitute one of the experiences of these youngsters and it has been well documented in research (Daniel, 1976; Ekwu, 1986; Fawole, Ajuwon \& Osungbade, 2004). Studies have also attributed the prevalence of sexual abuse to age of the respondents which may on the long run predispose them to unwanted pregnancy and the risk of sexually transmitted diseases due to their age (Ebigbo, 2003; Akpan \& Olubamide, 2010; Ekpenyong \& Sibiri, 2011). From observations, some of the findings from the study regarding the risk they face show that the day to day experiences of the streets have begun to rob off on the children as they are very cautious of disclosing information regarding their experiences as regards sexual abuse. Notwithstanding, this study has further demonstrated that abuse is a product of perceived social and economic vulnerability of the young traders; hurling insults on these young female traders constitutes a form of reaction to the failure of some of the female traders to yield to their sexual advances. As recorded during the interviews, these girls were often regarded as sex objects and when they refused to play along, abuse whether physically or otherwise constitutes one of the means of pressurising them into getting what they want or in some instances frustrate them on the trade. Some of these respondents in the process could bend to the pressure of abuse and succumb to their demands. Studies explaining the challenging circumstances of the traders generally attributed them to lack of recognition from the policy makers and poor organisation in terms of associations, (Alila \& Mitullah 2000). This study further sheds light on the individual circumstances of the young traders which also needs to be taken into consideration as well.

While available studies have not paid much attention to the perpetrators of abuse on the young female traders, evidence from this study demonstrated 


\section{Omotosho \& Ola - Negotiating Work Risks and Challenges}

that adults, and people known to these youngsters have been responsible for the abuse. They utilise experience, advantaged position coupled with the vulnerable nature of these youngsters to abuse them. Evidence demonstrated that education played a key role in creating awareness regarding the risks associated with unprotected sex; this alone may not shield these traders from abuse considering the individual they are dealing with on the streets.

\section{Conclusion}

This study investigated the experiences of the young female street traders in southwest Nigeria. A number of issues came up; first the young traders are exposed to the risks of abduction, sexual and other forms of abuse and accidents/injuries. These young ones are equally aware of the risks associated with the trade. Abusers of these children who are mostly adults and who patronise their products often used verbal and physical means in order to engage in sexual relations with them. One of the means by which these youngsters handle those experiences include adapting to the situation, sharing their experiences with their fellow friends mostly in the trade and their female parents/guardians. However, these significant others which the victims shared their experiences with were not able to handle the cases of abuse in a way that will prevent a future occurrence. Street traders have further devised the idea of not reporting the cases of abuse for the fear of ridicule and also not losing their customers who in most instances abuse them. From all indication, addressing the issue of risks associated with street trade might be a bit challenging. This study recommends the need to intensify awareness programmes aimed at educating the youngsters not only on the risks as quite a majority do, but on how they can avert the risk of abuse and other risks associated with the trade. Apart from this, further research may be needed to understand the social and economic characteristics of the parents and guardians of the street traders with the aim of educating them on how to protect the lives of the young ones. All these become critical as addressing poverty and culture, which are the main cause of street trade may not be feasible at the moment. 

10(1)

\section{References}

Adewumi, R. (2009). Facesmile functions of road safety, 25 people die daily. www.nigeriavillagesquare.com/articles/rowlandadewumi/topicadm.\&mgthtm

Adeyinka, S.A., Omisore, E.O., Olawunmi, P.O. \& Abegunde, A.A. (2006). An evaluation of informal sector activities on urban land use management in south western Nigeria. Shaping the Change XXIII FIG Congress Munich, Germany, Oct. 8-13.

Akarro, R. R. J. \& Mtweve, N. A. (2011). Poverty and its association with child labour in Njombe District in Tanzania: The case of Igima ward. Current Research Journal of Social Sciences 3(3):199-206.

Akpan, N. \& Olubamide, A. J. (2010). The menace of child abuse in Nigeria: A case study of street hawking in Uyo, Akwa Ibom State. Journal of Social Sciences. 24 (3) $189-182$.

Alila, P.O. \& Mitullah, W.V. (2000). Enhancing lobbying capacity of women street vendors: The challenges in the Kenyan policy environment. Nairobi: University of Nairobi, IDS.

Basu, K. \& Van, P. H. (1998). The economics of Chile labour. American Economic Review, 108, 663-679. DOI: 10.1257/aer.89.5.1386

Basu, K. (1999). Child labour: Causes, consequences and cure with remarks on International Labour Standards. Journal of Economic Literature, vol. 37, no.1, pp. 1083-1119. DOI: 10.1257/jel.37.3.1083

Bhat, B.A., \& Rather, T.A. (2009). Child labour in the handicrafts home industry in Kashmir: A sociological study International NGO Journal Vol. 4 (9), pp. 391-400, September, Available online at http:// www.academicjournals.org/ingoj ISSN 1993-8225

Charmes, J. (2000). Informal sector, poverty and gender: A review of empirical evidence. Paper commissioned for World Development Report 2000/1. Washington D.C., World Bank.

Daniel, H.J., (1976). Child abuse: A complex case of mis-socialization. In John Travors (ed). The New Children: The 1 st 6 years. Connecticut. Grey lock publisher: $67-113$. 


\section{Omotosho \& Ola - Negotiating Work Risks and Challenges}

Ebigbo, P. O. (2003). Street children: The core of child abuse and neglect in Nigeria. Children, Youth and Environments, 13(1). DOI 10.31686/ijier.vol7.iss2.1320

Ekpenyongi, S.A., \& Sibiri, A.E., (2011). Street trading and child labour in Yenegoa International Journal of Scientific Research in Education, March, Vol. 4(1), 36-46.

Ekwu, A.O. (1986). Health hazard in child labour: Case for juvenile hawkers. Proceeding of the 1st international workshop on shop child abuse in Africa. 27th April - 2nd May.

Emerson, P.M. (2009). Understanding child labour the economic view of child labour, in Hindman, H.D. (ed.) The World of Child Labour and Regional Survey. Pp.3-9. U.S.A: Myron, E.S.

Fawole, O.I., Ajuwon, A.J. \& Osungbade, K.O. (2004). Violence and HIV/AIDS prevention among female out of school youths in South Western Nigeria; lessons learned from interventions targeted at hawkers and apprentices. Afr J Med Sci. 2004: 33(4); 347- 353. DOI $10.2307 / 3583347$.

Fetuga, B.M., Njokanma, F.O., Olowu, A.O. (2005). Prevalence, types and demographic features of child labour among school children in Nigeria. BMC Inter Hlth Hum Rights 2005; 5: 2 - 8.

Freund, B. (2007). The African city, a history, Cambridge University Press.

Gbadamosi, K.T. (2006). The emergence of motorcycle in urban transportation in Nigeria and its implication on traffic safety. Association for European Transport and Contributors.

Ikechebelu, J.I., Udigwe, G.O., Ezechukwu, C.C., Ndinechi, A.G. \& Joe Ikechebelu, N.N. (2008). Sexual abuse among juvenile female street hawkers in Anambra State, Nigeria. Afr J Reprod Hlth 2008; 12 (2): 11 19. DOI: $10.2307 / 25470654$

International Labour Organization (2002). ILO compendium of official statistics on employment in the informal sector. STAT Working Paper, 2002-No.1.

International Labour Organization (2013). World report on child labour economic vulnerability, social protection and the fight against child labour. Geneva.

Iyenda, G. (2001). Street food and income generation for poor households in Kinshasa. Environment and Urbanisation, Vol. 13, No.2. 

10(1)

Jimu, I. (2005). Negotiated economic opportunity and power perspectives and perception of street vending in urban Malawi. Africa Development, Vol. XXX, No.4. DOI: 10.4314/ad.v30i4.22239

Lonrenço-Lindell, I. (2004). Trade and the politics of informalisation in Bissau, Guinea-Bissau. IN TRANBERG HANSEN, K. \& VAA, M. (Eds.) Reconsidering Informality, Perspectives from Urban Africa. Uppsala, Nordic Africa Institute.

Mapaure, C. (2009). Child labour: A universal problem from a Namibian perspective in OliverRuppel, ed, Children's Rights in Namibia, Windhoek: Konrad Adenauer Stiftung.

Omotosho, B.J and Toyin Adefolaju (2014). 'Attitude of Civil Servants to Domestic Helpers in Southwest Nigeria' European Journal of Research in Social Sciences Vol 2 No 1 Progressive Academic Publishing pp16-27.

Omotosho, B.J (2009). Gender Discrimination in the Workplace: A Myth or Reality Faculty of Social Science Journal Vol 4 no1 pp 152-161University of Ado Ekiti.

Onakomaiya, S.O. (1988). Unsafe at any speed: Towards road transportation for survival, Ilorin: University of Ilorin Monograph.

Osinowo, O.A. (1992). Street children and psychological consequences. Int $\mathrm{J}$ of Rep Health, 4; 101-108.

Padayachee, V. (2010). The Political Economy of Africa Routledge. DOI https://doi.org/10.4324/9780203854228

Sherman, D.J. (1992). The neglected health care needs of street youth. Public Health Rep. 107(4); 433-440.

Skinner, C. (2008). Street trade in Africa: a review. Centre for Development Studies Working Paper 51, University of KwaZulu-Natal.

The Tide (2010). Street trading and hawkers in PH.

http://www.thetidenewsonline.com/2010/06/19/street-trading-andhawkers-in-ph/

Tsitsi, N., \& Agatha, T. (2000). Women street vendors in Zimbabwe. Women and Law in Southern Africa Research and Education Trust, 37 Paper commissioned by Women in Informal Employment: Globalising and Organising.

UNICEF (2000). Nigeria and the Convention on the Rights of the Child. Lagos: UNICEF Country Office. 
69 Omotosho \& Ola - Negotiating Work Risks and Challenges

UNICEF (2008). Sexual Abuse And Exploitation Of Children In West And Central Africa Developments, progress and challenges since the Yokohama Congress (2001) and the Rabat Arab-African Forum (2004) UNICEF West and Central Africa Regional Office

Witt, H. (2000). Formal and informal economic linkages in the fruit and vegetable sector. Study 23, Research report for the Durban Metro Technical Task Team for the Informal Economy, Durban.

World Health Organisation (2017). The Ecological Framework Violence Prevention Alliance Global Campaign For Violence Prevention World Health

http://www.who.int/violenceprevention/approach/ecology/en/

Organisation.

Babatunde Joshua Omotosho: Federal University Oye-Ekiti

E-mail address: babatunde.omotosho@fuoye.edu.ng

Muhammed Y. Ola 